Prepared for the U.S. Department of Energy under Contract DE-AC05-76RL01830

\title{
Summary Report for the Radiation Detection for Nuclear Security Summer School 2012
}

RC Runkle

JE Baciak

JA Stave

August 2012

\section{Pacific Northwest}

NATIONAL LABORATORY

Proudly Operated by Battelle Since 1965 



\title{
DISCLAIMER
}

This report was prepared as an account of work sponsored by an agency of the United States Government. Neither the United States Government nor any agency thereof, nor Battelle Memorial Institute, nor any of their employees, makes any warranty, express or implied, or assumes any legal liability or responsibility for the accuracy, completeness, or usefulness of any information, apparatus, product, or process disclosed, or represents that its use would not infringe privately owned rights. Reference herein to any specific commercial product, process, or service by trade name, trademark, manufacturer, or otherwise does not necessarily constitute or imply its endorsement, recommendation, or favoring by the United States Government or any agency thereof, or Battelle Memorial Institute. The views and opinions of authors expressed herein do not necessarily state or reflect those of the United States Government or any agency thereof.

\author{
PACIFIC NORTHWEST NATIONAL LABORATORY \\ operated by \\ BATTELLE \\ for the \\ UNITED STATES DEPARTMENT OF ENERGY \\ under Contract DE-AC05-76RL01830
}

Printed in the United States of America
Available to DOE and DOE contractors from the Office of Scientific and Technical Information,
P.O. Box 62, Oak Ridge, TN 37831-0062;
ph: (865) 576-8401
fax: $(865)$ 576-5728
email: reports@adonis.osti.gov

\begin{abstract}
Available to the public from the National Technical Information Service, U.S. Department of Commerce, 5285 Port Royal Rd., Springfield, VA 22161 ph: (800) 553-6847 fax: $(703) 605-6900$ email: orders@ntis.fedworld.gov online ordering: http://www.ntis.gov/ordering.htm
\end{abstract}

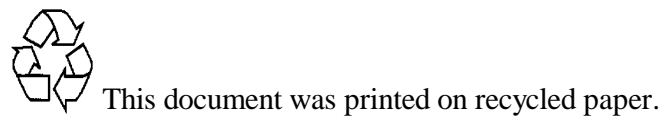




\title{
Summary Report for the Radiation Detection for Nuclear Security Summer School 2012
}

\author{
RC Runkle \\ JE Baciak \\ JA Stave
}

August 2012

Prepared for

the U.S. Department of Energy

under Contract DE-AC05-76RL01830

Pacific Northwest National Laboratory

Richland, Washington 99352 



\section{Executive Summary}

The Pacific Northwest National Laboratory (PNNL) hosted students from across the United States at the inaugural Radiation Detection for Nuclear Security Summer School from June $11-22,2012$. The summer school provided students with a unique understanding of nuclear security challenges faced in the field and exposed them to the technical foundations, analyses, and insight that will be required by future leaders in technology development and implementation. The course heavily emphasized laboratory and field demonstrations including direct measurements of special nuclear material. The first week of the summer school focused on the foundational knowledge required by technology practitioners; the second week focused on contemporary applications. Student evaluations and feedback from student advisors indicates that the summer school achieved its objectives of 1) exposing students to the range of nuclear security applications for which radiation detection is necessary, 2) articulating the relevance of student research into the broader context, and 3) exciting students about the possibility of future careers in nuclear security.

Table 1. Key Summer School Facts and Findings

\section{ATTENDANCE}

number

We limited enrollment in the summer school to 12 individuals because of the limited capacity of activities and tours. These students, including 11 graduate students and 1 undergraduate, were all U.S. citizens and came from universities across the country. An additional 3 student interns at PNNL expressed interest in the summer school based on their summer research. We invited them to attend the lectures. The students recommended that the summer school be kept small in future years.

backgrounds To our surprise, the students possessed diverse academic backgrounds that included nuclear engineering, nuclear physics, chemistry, chemical engineering, mechanical engineering, materials science, and geology. All of the students expressed interest in career opportunities in nuclear security, although not necessary as federal employees.

origins

Students from the following universities participated: North Carolina State University, Penn State University (2), State University of New York Stony Brook, University of Arizona, University of California Berkeley (2), University of Michigan, University of Nevada Las Vegas, University of Notre Dame, University of Texas Austin, University of Washington, and Washington State University.

\section{CURRICULUM}

lectures

The largest element of the summer school was a collection of 13 lectures. These lectures covered topics spanning nuclear security missions, signatures accessible via radiation detection, gamma-ray and neutron detection, active interrogation, nuclear security systems, and future opportunities.

guest lectures

Eight guest lectures allowed students to interact in a small group setting with national experts on a range of contemporary topics that included treaty verification, nuclear material interdiction, and nuclear safeguards. 


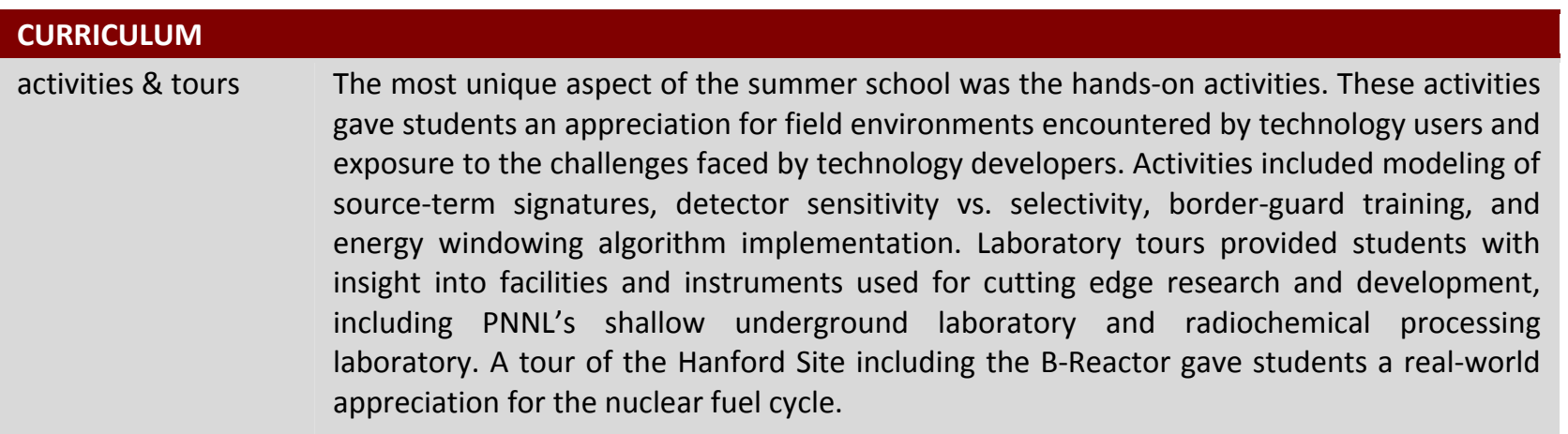

student lectures Students whose thesis work was of an appropriate maturity level briefed their projects. These presentations allowed the instructors to articulate the relevance of student work in the larger nuclear security picture and to provide guidance on future work and potential collaborations across the national laboratory complex.

\section{FEEDBACK \& LESSONS LEARNED}

student evaluations Students completed an evaluation form that provided both quantitative feedback to prescribed questions and qualitative feedback that specifically requested recommendations for course improvement. The students unanimously agreed that the summer school was informative and engaging, and that it improved their understanding of the nuclear security mission and how radiation detection relates to nuclear security. The highest scoring element was the guest lecture series; 85 percent of the students strongly agreed that these lectures improved understanding of the challenges associated with the wide scope of nuclear security. There was a diversity of recommendations for improvements with no particular theme, but a few reoccurring points were to 1) add a neutron detection activity, 2 ) add more in-depth discussion of advanced techniques, and 3 ) provide time for socialization with the guest speakers.

key lessons learned Activities and guest lectures formed the unique nature of the summer school. While these activities consumed most of the time, they should be expanded to be an even larger element.

The foundational lecture materials were delivered too quickly; students found it difficult to keep up with the material. These lectures should be shortened and intertwined with guest lectures to allow more time to absorb concepts.

Perhaps the most important lesson is that execution of the summer school requires far more logistical gymnastics than originally expected; flexibility in shifting activities and lectures and their locations was one key to success. 


\section{Contents}

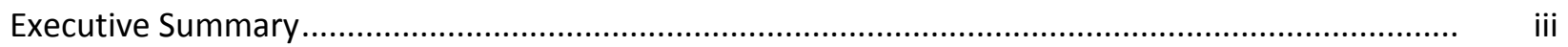

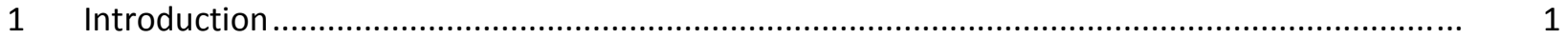

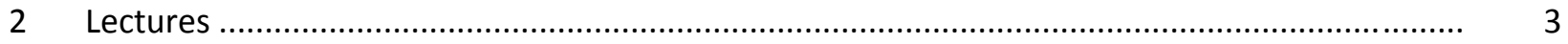

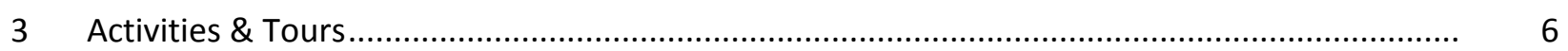

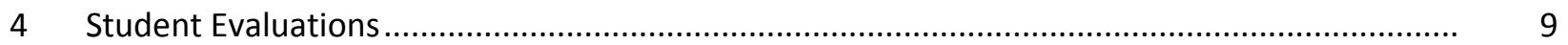

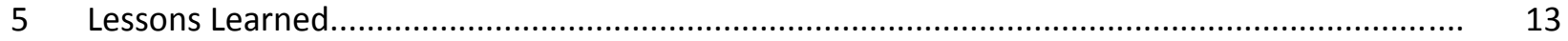

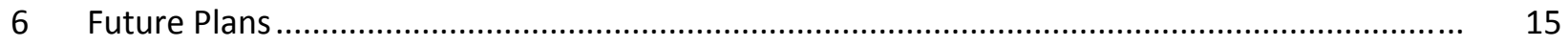

Appendix A - Summer School Flyer ..................................................................................... A

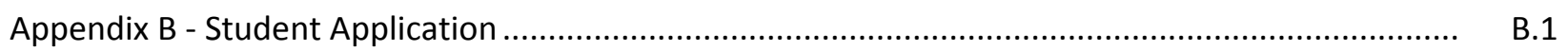

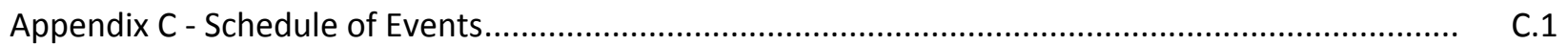

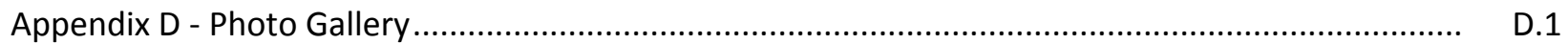

Appendix E - Extracurricular Activities ....................................................................................... E.1 


\section{Introduction}

The Pacific Northwest National Laboratory (PNNL) hosted students from across the United States at the inaugural Radiation Detection for Nuclear Security Summer School from June $11-22,2012$. These students, including 11 graduate students and one undergraduate, were all U.S. citizens and came from universities across the country. An additional three student interns at PNNL expressed interest in the summer school based on their summer research. We invited these three to attend the lectures. This small enrollment, originally recommended by NA-22 program management, was an excellent size that fostered an intimate atmosphere conducive to sidebar discussions and in-depth involvement in activities. Both the instructors and the students recommend that the summer school be kept small in future years. Table 2 lists the graduate student participants; Figure 1 shows a photograph.

Our original expectation was that the student body would be comprised primarily of students whose thesis research involved radiation detection. To our surprise, the students possessed a more diverse academic background that included nuclear engineering, nuclear physics, chemistry, chemical engineering, mechanical engineering, materials science, and geology. In most cases, radiation detection was an element of student research but not necessarily the focus or critical element. This made the course particularly enlightening and challenging for some students.

Table 2. Graduate Students In Attendance

\begin{tabular}{|c|c|c|c|}
\hline STUDENT & UNIVERSITY & FIELD OF STUDY & GRADUATE THESIS \\
\hline Bailey, Zachary & NC State & $\begin{array}{l}\text { Nuclear } \\
\text { Engineering }\end{array}$ & $\begin{array}{l}\text { Improving Pulse Shape Analysis with a } \\
\text { Liquid Organic Scintillator and a Fast } \\
\text { Waveform Digitizer }\end{array}$ \\
\hline Brasfield, Daniel & Univ of TN & $\begin{array}{l}\text { Materials } \\
\text { Chemistry }\end{array}$ & $\begin{array}{l}\text { Optimization of Boron Phosphide Thin } \\
\text { Films for Thermal Neutron Detection }\end{array}$ \\
\hline Czeszumska, Aga & UC-Berkeley & $\begin{array}{l}\text { Nuclear } \\
\text { Engineering }\end{array}$ & $\begin{array}{l}\text { Determining } 239 N p(n, f) \text { Cross Section } \\
\text { Using the Surrogate Ratio Method }\end{array}$ \\
\hline Faye, Sherry & UNLV & $\begin{array}{l}\text { Radiochemistry } \\
\text { Ph.D. }\end{array}$ & $\begin{array}{l}\text { Optimization of a Sequential Extraction } \\
\text { Procedure for Analysis of Multiple } \\
\text { Actinide Elements }\end{array}$ \\
\hline Ko, Phyllis & Penn State & $\begin{array}{l}\text { Nuclear } \\
\text { Engineering }\end{array}$ & $\begin{array}{l}\text { Laser-Induced Breakdown } \\
\text { Spectroscopy for Nuclear Forensics }\end{array}$ \\
\hline Koeman, Elizabeth & Notre Dame & Geology & $\begin{array}{l}\text { Multi-Scale Separation and Analysis of } \\
\text { Heterogeneous Trinitite Phases }\end{array}$ \\
\hline Le, Linh & Univ of NM & Ph.D. in Physics & $\begin{array}{l}\text { Magnetic Micro-Calorimeters for } \\
\text { Gamma Ray Detection }\end{array}$ \\
\hline Lu, Christopher & UT - Austin & $\begin{array}{l}\text { Nuclear \& } \\
\text { Radiation } \\
\text { Engineering }\end{array}$ & $\begin{array}{l}\text { U-235 Fission Product Yield } \\
\text { Determination }\end{array}$ \\
\hline
\end{tabular}




\begin{tabular}{|lll|l}
\hline \multicolumn{1}{|c|}{ STUDENT } & \multicolumn{1}{c|}{ UNIVERSITY } & FIELD OF STUDY & GRADUATE THESIS \\
\hline McNutt, Jessica & Penn State & $\begin{array}{l}\text { Nuclear } \\
\text { Engineering }\end{array}$ & $\begin{array}{l}\text { Laser-Induced Breakdown } \\
\text { Spectroscopy for Nuclear Forensics }\end{array}$ \\
Miller, Brian & Univ of Arizona & Optical Sciences & $\begin{array}{l}\text { High-Resolution Gamma-Ray Detectors } \\
\text { for Pre-Clinical SPECT }\end{array}$ \\
Shoulder, Racheal & Univ of WA & Physics, M.S & Electric fields of the human brain
\end{tabular}

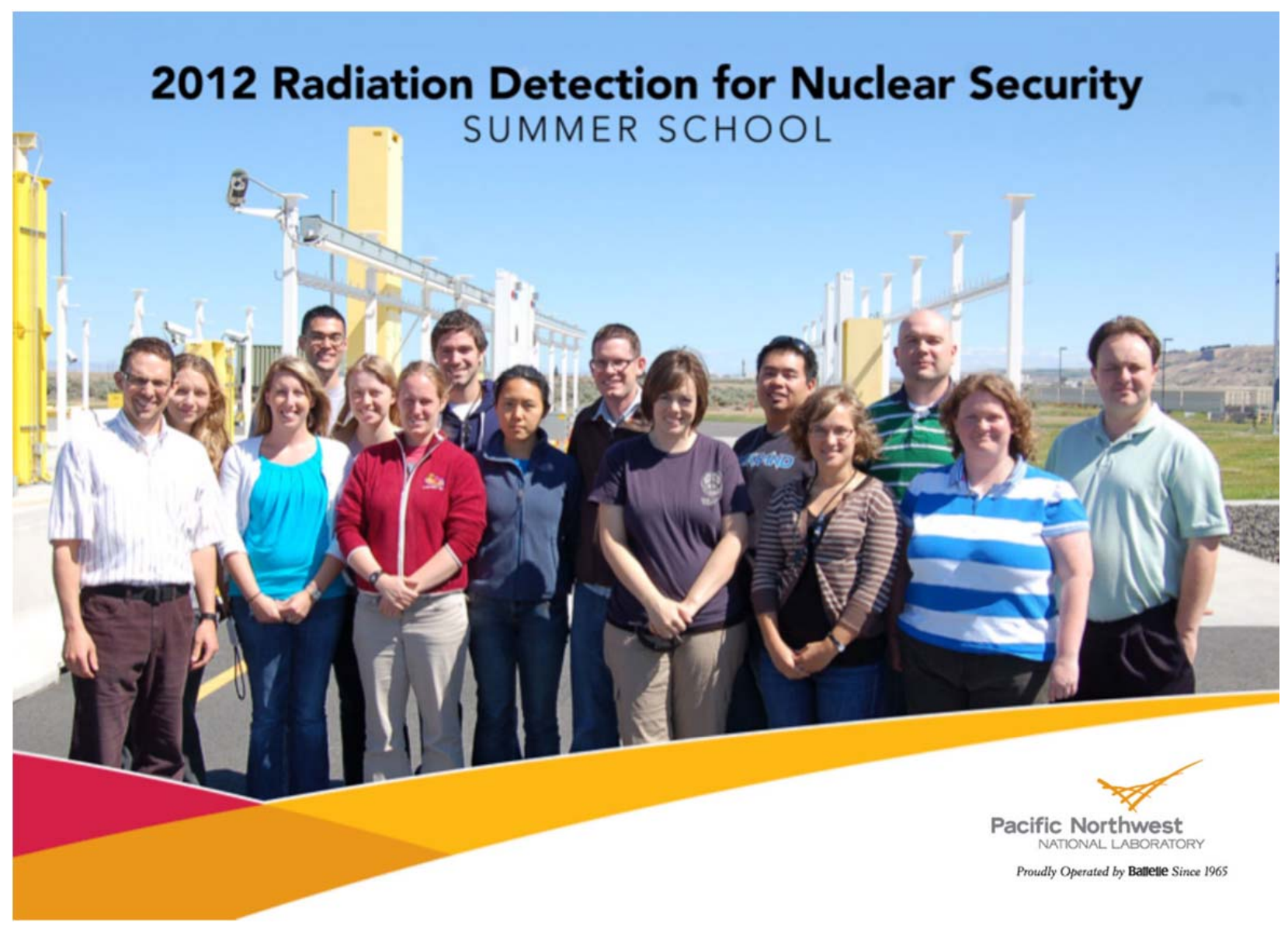

Figure 1. Group Photograph of Summer School Participants and Instructors. Each student received an autographed copy. 


\section{Lectures}

The summer school lectures were bifurcated into two discrete weeks. The first week covered foundational knowledge of radiation detection and its application in nuclear security. This included both the physics of radiation detection and specific systems and methods deployed in nuclear security missions (Table 3). The second week consisted of a series of topical guest lectures delivered by a set of national and international subject matter experts ( 
Table 4).

Table 3. Listing of Lectures

\begin{tabular}{|c|c|c|}
\hline LECTURE NUMBER & LECTURE TITLE & LECTURER \\
\hline 1 & The Nuclear Security Mission & Robert Runkle \\
\hline 2 & $\begin{array}{l}\text { The Physics of Fission, Nuclear Fuel, Enrichment, and } \\
\text { Reactors }\end{array}$ & James Baciak \\
\hline 3 & Signatures of Special Nuclear Material & Robert Runkle \\
\hline 4 & $\begin{array}{l}\text { Overview of Modeling and Simulation Techniques for } \\
\text { Radiation Detection in Nuclear Security }\end{array}$ & James Baciak \\
\hline 5 & Fundamentals of Radiation Detection: Gamma-Rays & James Baciak \\
\hline 6 & Gamma-ray Detection \& Spectroscopy & Robert Runkle \\
\hline 7 & Fundamentals of Radiation Detection: Neutrons & James Baciak \\
\hline 8 & Neutron Detection Systems & Robert Runkle \\
\hline 9 & $\begin{array}{l}\text { Gamma-Ray and Neutron Imaging for Nuclear Security } \\
\text { Applications }\end{array}$ & James Baciak \\
\hline 10 & Active Interrogation Methods & Robert Runkle \\
\hline 11 & Systems Level View of Nuclear Security & Robert Runkle \\
\hline 12 & Detection of Nuclear Materials by Other Means & Jean Stave \\
\hline 13 & Emerging Trends \& Opportunities & Robert Runkle \\
\hline
\end{tabular}


Table 4. Listing of Guest Lectures

\begin{tabular}{|r|l|l|}
\hline LECTURE NUMBER & LECTURE TITLE & LECTURER \\
\hline 2 & It's The End Of ${ }^{3}$ He As We Know It & Richard Kouzes \\
3 & $\begin{array}{l}\text { The Comprehensive Nuclear-Test-Ban Treaty: A } \\
\text { Detector Geek's Perspective }\end{array}$ & Carolyn Seifert \\
4 & $\begin{array}{l}\text { Forks, Pythons, and the Holy Grail } \\
\text { The Evolution of Spent Fuel Safeguards }\end{array}$ & Marc Humphrey (NNSA) \\
5 & $\begin{array}{l}\text { Second Line of Defense Program A Key Element of the } \\
\text { Global Nuclear Security Framework }\end{array}$ & David Kostorowski \\
6 & $\begin{array}{l}\text { Dr., Dr., Give Me the News, I have a Weird Spectrum } \\
\text { and I am Very Confused }\end{array}$ & Jason Shergur \\
$7 A$ & $\begin{array}{l}\text { IAEA Safeguards Inspections: Policy Drivers \& } \\
\text { Technology Requirements } \\
7 B\end{array}$ & $\begin{array}{l}\text { The Science Behind Modern Day Nuclear Forensic } \\
\text { Analysis Definition, Importance, and Example }\end{array}$
\end{tabular}




\section{Activities \& Tours}

The activities and laboratory tours were the highlight of the summer school course in several ways, most notably because they provided students with hands-on experience using detectors, such as those in Figure 2 that are currently deployed in operational environments. The primary goal of the activities was to demonstrate the constraints faced by technology operators, for example the difficulty of carrying the sometimes heavy instrumentation. Table 5 provides a summary of these activities.

A set of laboratory and off-site tours gave students an in-depth appreciation of specialized instruments used in various nuclear security settings. These included a visit to the SAUNA (Swedish Automatic Unit for Noble Gas Acquisition) system which is designed for low-level measurement of radioxenon. These systems are used as part of the International Monitoring System network of the Comprehensive Test Ban Treaty Organization. Students were also given a tour of the shallow underground laboratory where low-background detectors are assembled, tested, and used for national security applications; the Radiochemical Processing Laboratory (RPL) used for research in cleanup of radiological wastes, processing and disposal of nuclear fuels, and production and delivery of medical isotopes occurs; and the Radiological Calibrations Laboratory which provides technical services and testing for a large variety of radiological instrumentation and dosimetry.

Table 5. Summary of Activities and Tours

\begin{tabular}{|c|c|c|}
\hline ACTIVITY/TOUR & PURPOSE & LOCATION \\
\hline $\begin{array}{l}\text { Modeling Source Terms } \\
\text { and Detector Response }\end{array}$ & $\begin{array}{l}\text { Introduce students to the modeling software } \\
\text { SYNTH and use this software to explore the } \\
\text { variety of factors that impact the signatures, } \\
\text { primarily gamma-ray emissions, of bulk special } \\
\text { nuclear material. }\end{array}$ & $\mathrm{N} / \mathrm{A}$ \\
\hline $\begin{array}{l}\text { Radiation Detectors: } \\
\text { Sensitivity vs. Selectivity }\end{array}$ & $\begin{array}{l}\text { Use a variety of radiation detectors with } \\
\text { differing efficiencies and energy resolutions to } \\
\text { measure the energy of gamma rays emitted by } \\
\text { low-activity sources commonly used to } \\
\text { calibrate and characterize detection systems. }\end{array}$ & Large Detector Laboratory \\
\hline Laboratory tours & $\begin{array}{l}\text { Expose students to operational facilities and } \\
\text { research and development laboratories. }\end{array}$ & $\begin{array}{l}\text { Swedish Automatic Unit for Noble } \\
\text { Gas Acquisition, Shallow } \\
\text { Underground Laboratory, } \\
\text { Radiochemical Processing } \\
\text { Laboratory, Radiological } \\
\text { Calibrations Laboratory }\end{array}$ \\
\hline B Reactor Tour & $\begin{array}{l}\text { Visit the site of the world's first industrial-scale } \\
\text { nuclear reactor and learn about its } \\
\text { development, construction, and operation } \\
\text { during the Manhattan Project. }\end{array}$ & Hanford Site (see Figure 3) \\
\hline
\end{tabular}




\begin{tabular}{|c|c|c|}
\hline ACTIVITY/TOUR & PURPOSE & LOCATION \\
\hline $\begin{array}{l}\text { Determining the } \\
\text { Sensitivity of Radiation } \\
\text { Portal Monitors }\end{array}$ & $\begin{array}{l}\text { Introduce students to the operation of cargo } \\
\text { and vehicle radiation portal monitors, including } \\
\text { energy window discrimination, and observe the } \\
\text { effects of shielding and naturally occurring } \\
\text { radioactive material on the capability of portal } \\
\text { monitors to detect special nuclear material. }\end{array}$ & $\begin{array}{l}\text { Large Detector Laboratory Test } \\
\text { Track }\end{array}$ \\
\hline Border Guard Training & $\begin{array}{l}\text { Participate in a border guard training activity } \\
\text { that includes locating and identifying sources in } \\
\text { a realistic setting. }\end{array}$ & $\begin{array}{l}\text { Volpentest HAMMER Training and } \\
\text { Education Center }\end{array}$ \\
\hline
\end{tabular}
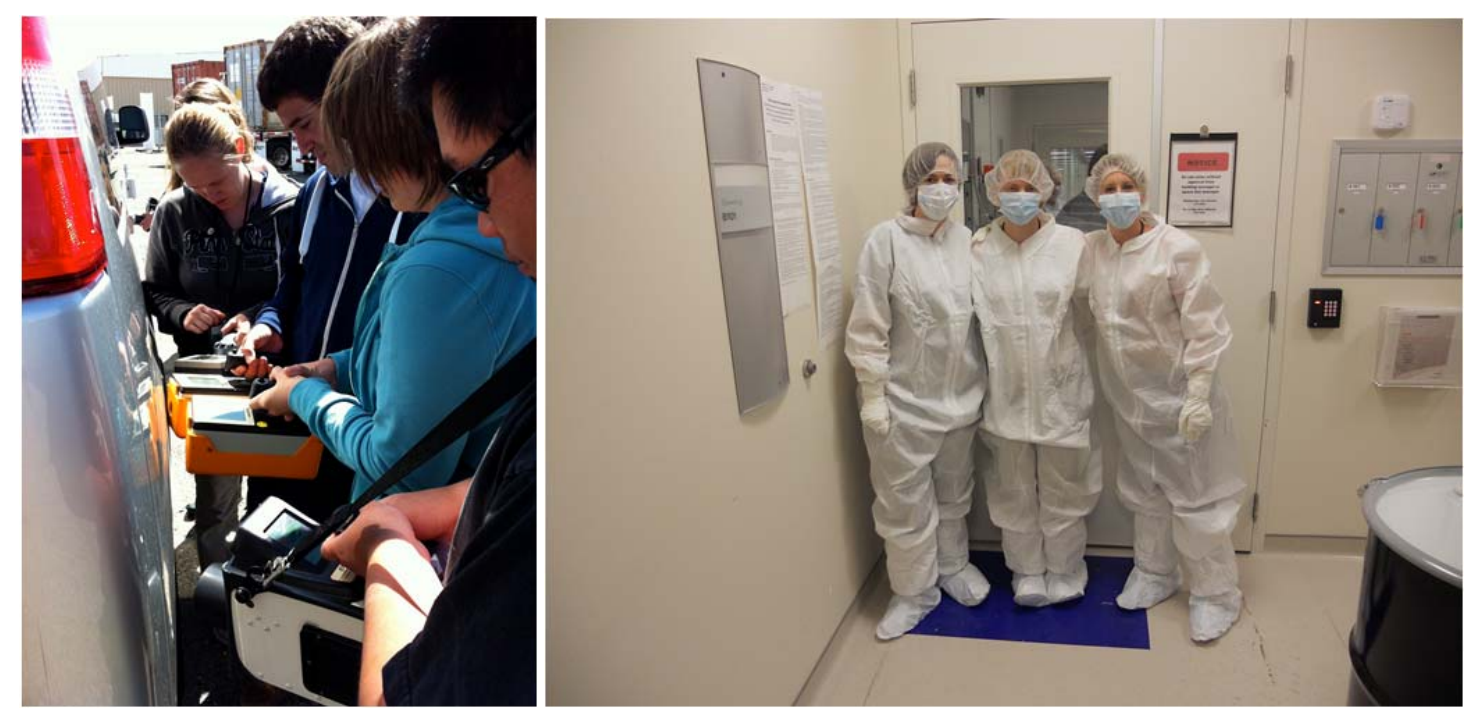

Figure 2. On left, students using handheld radiation detectors to both locate and identify radiation sources in a van. On right, students don clean-room gear before entering the shallow underground laboratory. 


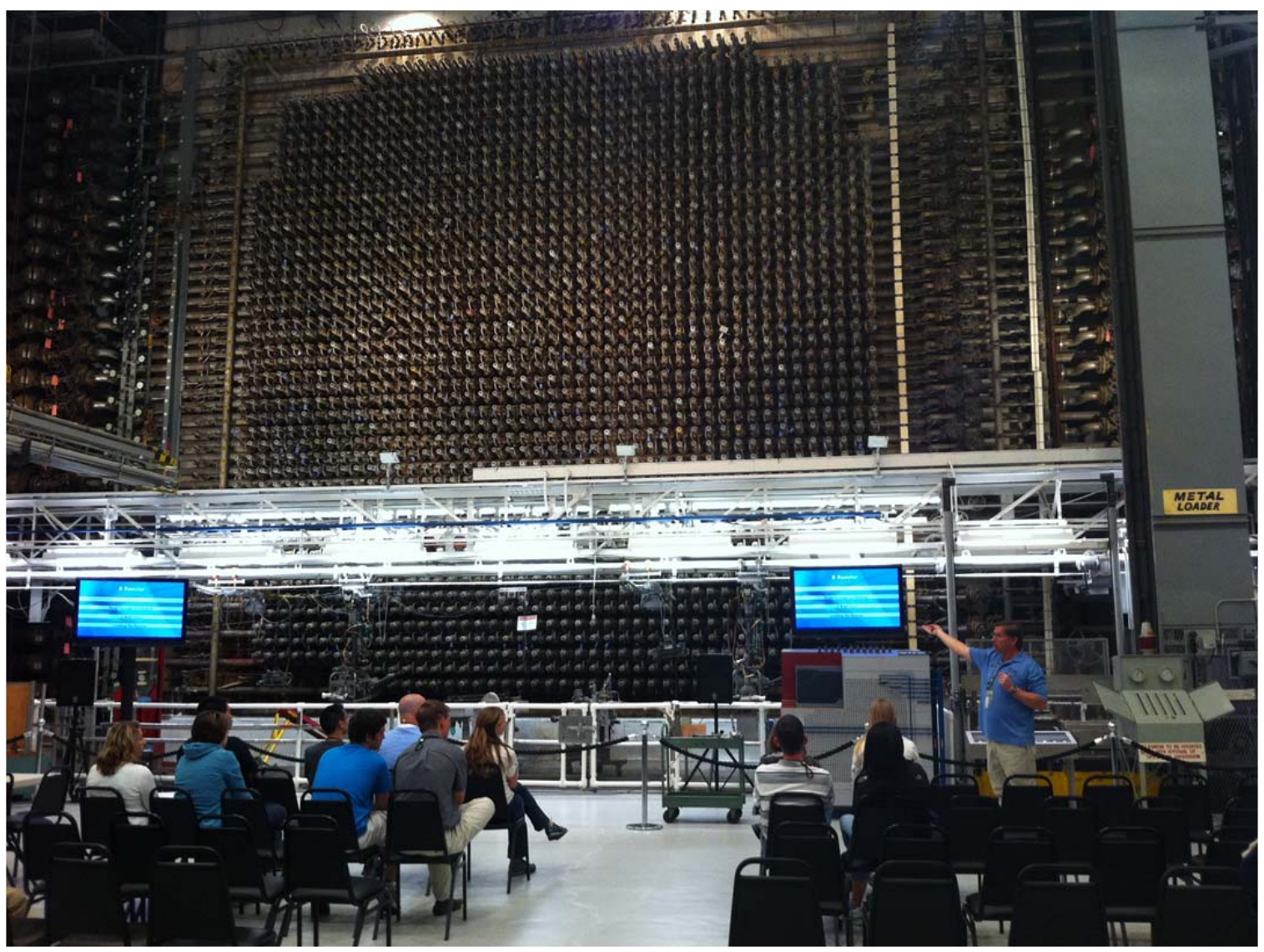

Figure 3. Students learn about the history and operation of the B Reactor, the first industrial-scale nuclear reactor, during a tour of the Hanford site. The B Reactor tour begins in the work area facing the front face of the reactor where new fuel elements were loaded into the process tubes. 


\section{Student Evaluations}

Students completed an evaluation form that provided both quantitative feedback to prescribed questions and qualitative feedback that specifically requested recommendations for course improvement. The students unanimously agreed that the summer school was informative and engaging, improved their understanding of the nuclear security mission and how radiation detection relates to nuclear security. The highest scoring element was the guest lectures; 85 percent of the students strongly agreed that these lectures improved understanding of the challenges associated with the wide scope of nuclear security. There was a diversity of recommendations for improvements with no particular theme, but a few reoccurring points were to i) add a neutron detection activity, ii) add more in-depth discussion of advanced techniques, iii) provide time for socialization with the guest speakers.

The students identified a variety of favorite aspects of the course that they found especially enjoyable or useful. The most common response was to the hands-on activities, especially the opportunity to work with the radiation portal monitors (RPMs) at the PNNL test track. Other frequently mentioned favorites included i) guest lectures on a variety of current topics by experts in nuclear security, ii) tours of operating labs and particularly of the decommissioned B Reactor and iii) the opportunity to meet and work with other students in fields related to nuclear security and to learn about each other's work. Other responses mentioned that students also appreciated the opportunity to speak informally with PNNL scientists, the small size of the student group and the course materials provided.

Although the response was mostly positive to the course, the most common complaints from students involved the format of the lectures; students suggested making the lectures more interactive, cover fewer topics so that some lectures were not as rushed, and modifying the IAEA guest lectures (7A and 7B). Other areas for improvement included the modeling activity and the lecture portion of the HAMMER border guard training. 
Table 6 lists quantitative ratings from student surveys. Unabridged student comments include the following.

\section{When asked "My favorite part of the Summer School was"}

- The activities were not only fun, but helped my understanding of detection. The lab tours were also fun. But Reactor B was my favorite.

- All of the different guest lectures given by great names in the individual fields. It was also really cool hearing about what other students are doing out there in the world of research and how those skills could be used in a security capacity.

- Using the RPMs to test the windowing algorithms we invented, seeing B Reactor, listening to student presenters, hearing the IAEA inspector.

- The guest lectures as well as the activities. I also loved the book with all the lecture slides. The various scientists who gave us tours were great because we had the opportunity to talk informally about their work as well as their experiences.

- Being at the lab, networking with other interested students, and being actively involved in the course.

\section{When asked "I would make improvements to the Summer School by"}

- I would suggest that the course provide reading material ahead of the course to reduce the demand for so many lectures at the beginning. The content delivered in the lectures was great, but it was so much that it became really difficult to focus. I know this might be challenging, but it would have been nice to have had time after the guest lectures to talk, informally, with the speakers.

- Adding a few guest lectures or spread out the guest lectures so they are offered both weeks.

- Have a neutron activity! Do some more work with detectors in general. Maybe a basic experiment and analysis-or an experiment with coincidence counting.

- Some of the more advanced concepts were not discussed in as much detail: I think it would have been useful to have both in-depth fundamental concepts (which did happen), and indepth advanced concepts.

- Streamline the activities. Data could be provided beforehand and more active discussion could take place during activity time. 
Table 6. Student Ratings from Summer School Survey

\begin{tabular}{l|l|l|l|l|} 
Strongly Agree & Agree & Neutral & Sisagree
\end{tabular}

1. I found the Radiation Detection for Nuclear Security Summer School to be informative and engaging.

$85 \% \quad 15 \%$

2. The Radiation Detection for Nuclear Security Summer School improved my understanding of the nuclear security mission.
$62 \%$
$38 \%$

3. I believe the Radiation Detection for Nuclear Security Summer School enhanced my understanding of radiation detection as applied to nuclear security.

$85 \% \quad 15 \%$

4. The activities/experiments performed within the Summer School were useful.

$77 \% \quad 23 \%$

5. The facility tours were engaging and enhanced your understanding of the nuclear security mission.
$62 \%$
$13 \%$
$8 \%$

6. The guest lectures provided improved understanding of the challenges associated with the wide scope of nuclear security.

$85 \% \quad 15 \%$

7. Having student participants present on their research is an important part of the summer school agenda.
$23 \%$
$69 \%$
$8 \%$

8. I would recommend the Radiation Detection for Nuclear Security Summer School to other students.

$69 \% \quad 31 \%$

9. Participation in the Radiation Detection for Nuclear Security Summer School has increased my interest working within the nuclear security mission at national laboratories, or for the federal government.

$46 \%$

$46 \%$

$8 \%$ 



\section{$5 \quad$ Lessons Learned}

\subsection{Lectures}

1. The original schedule included generous allotments of time for lectures and some dedicated time for discussion. Despite this, more time was needed for general discussion and reflection on lecture materials.

2. Lecture development took more time than we expected. Although many of the lectures developed can be used in future sessions, the time allotted for the creation of new lectures should be increased.

3. Due to scheduling conflicts that arose just before the start of the course, the preferred location for lectures was not always available and the new locations were not always ideal. In the future, alternate locations will be reserved as well as our preferred one in case such schedule changes occur again.

\subsection{Activities}

4. Part of the hands-on nature for the activities included students working in teams to setup measurement parameters or to analyze collected data. These tasks would be more efficiently executed as homework or as unstructured time at the end of each day. This allows students to spend varying amounts of time on tasks.

5. The modeling software used, SYNTH, can only be run on Windows computers. Students should be asked whether they plan to bring a Windows or Apple laptop and more laptops with SYNTH preloaded should be made available.

6. Prior to student engagement, more time should be scheduled during the course to set up activities ahead of time and to later dismantle them.

\subsection{Tours}

7. Laboratory tours should be scheduled more evenly through the two week course, and tours should be scheduled so that access restrictions do not conflict, in particular for the shallow underground laboratory.

8. The addition of a tour of the Physical Science Facility should be considered as well as including the naval reactor in the B-Reactor/Hanford Site tour. 



\section{Future Plans}

By essentially all metrics the inaugural summer school was a success. There were few surprises and the group of students in attendance was exceptional. In formulating the summer school, the desire for cost effectiveness imposed constraints on the breadth of topics and activities in the 2012 curriculum. The current course curriculum could be repeated as is in future years, but there are several key areas for improvement.

It was clear from the energy in the room that the activities were the most impressive aspect of the summer school. While also the most expensive to plan and execute, these activities most directly achieve the summer school's goals. The most effective path towards improving the summer school is thus to expand both the depth of existing activities and to supplement the curriculum with additional activities. In particular, addition of a neutron measurement is critical. Not far behind is the need for a safeguards-relevant measurement, for example one focused on spectroscopic analysis of varying levels of uranium enrichment. Another candidate is the analysis of spectroscopic measurements of spent nuclear fuel.

Topics of particular contemporary interest relevant to the Comprehensive Nuclear Test Ban Treaty and the proposed Fissile Material Cutoff Treaty were covered as part of the guest lectures and in the "Systems Level View of Nuclear Security Lecture". Other topics relevant to nuclear safeguards were addressed in the lectures and guest lectures but not at the desirable level of detail. Expanding the breadth of the base set of lectures, while sacrificing some detail in existing lectures, would elevate the impact and relevance of the summer school. 
Appendix A

Summer School Flyer 


\section{7 \\ Radiation Detection for Nuclear Security Summer School}

Pacific Northwest

NATIONAL LABORATORY
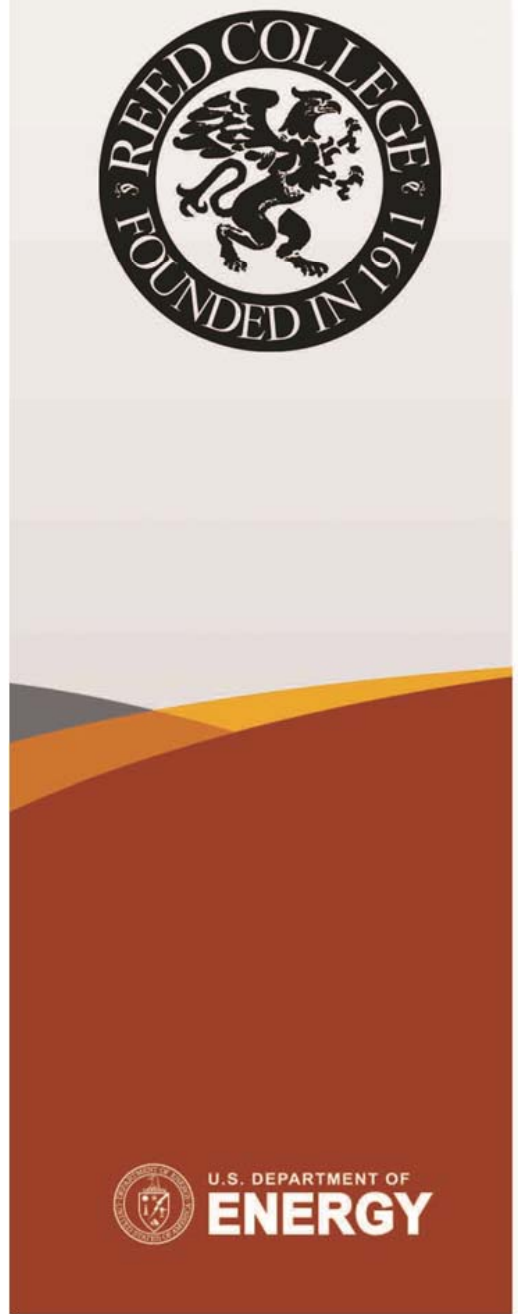

Pacific Northwest National Laboratory is pleased to offer a new summer school course that emphasizes the needs for radiation detection in nuclear security. We will provide students with a unique understanding of nuclear security challenges faced in the field and expose them to the technical foundations, analyses, and insight that will be required by future leaders in technology development and applications relevant to nuclear security missions. The course will heavily emphasize laboratory and field demonstrations, including direct measurments of special nuclear material, and students will attend seminars given by top experts in the field. We will enroll approximately 12 students in a 2-week summer school that combines lectures, real-world technology demonstrations, and tours of operational facilities with relevance to nuclear security.

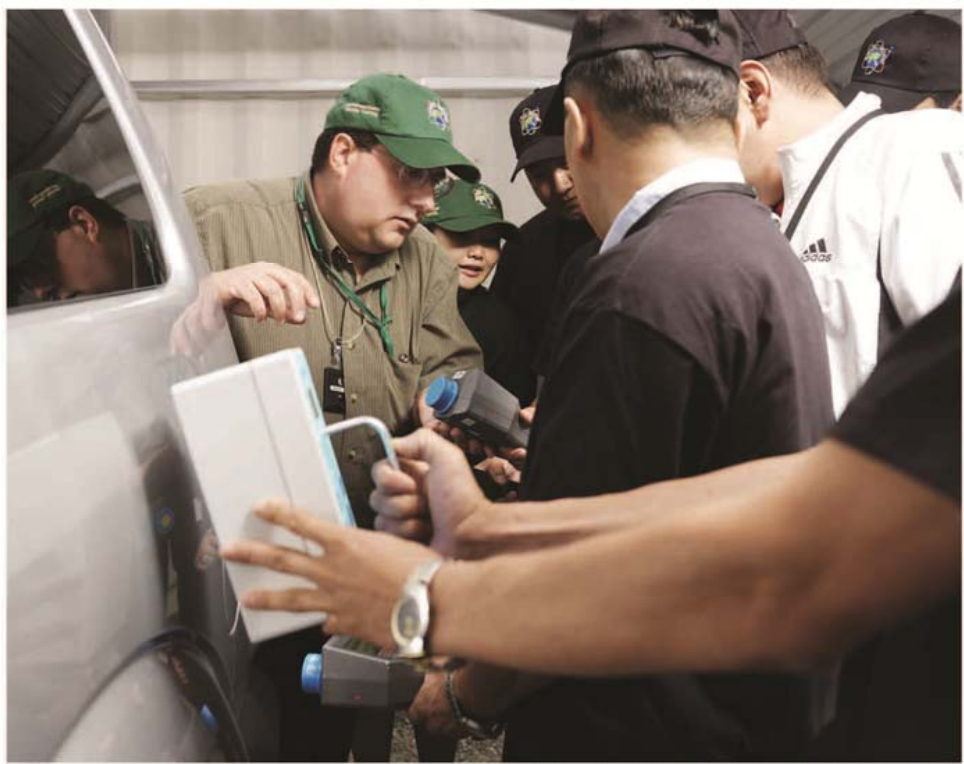

Officers train to intercept smuggled nuclear material to reduce the threat of nuclear proliferation using handheld radiation detection devices.

There is no charge for the course, but students are responsible for transportation to and from the class, meals and lodging. Information on local airports, rental agencies, public transportation and available lodging will be provided. Students will also present a 15 minute presentation on their own research.

Mark Your Calendar:

First Week: Reed College, Portland, OR, June 11-15, 2012

Second Week: Pacific Northwest National Laboratory, Richland, WA June 18-22, 2012

Application Deadline: March 1, 2012

Funded by: NNSA Office of Nonproliferation and Verification R\&D 


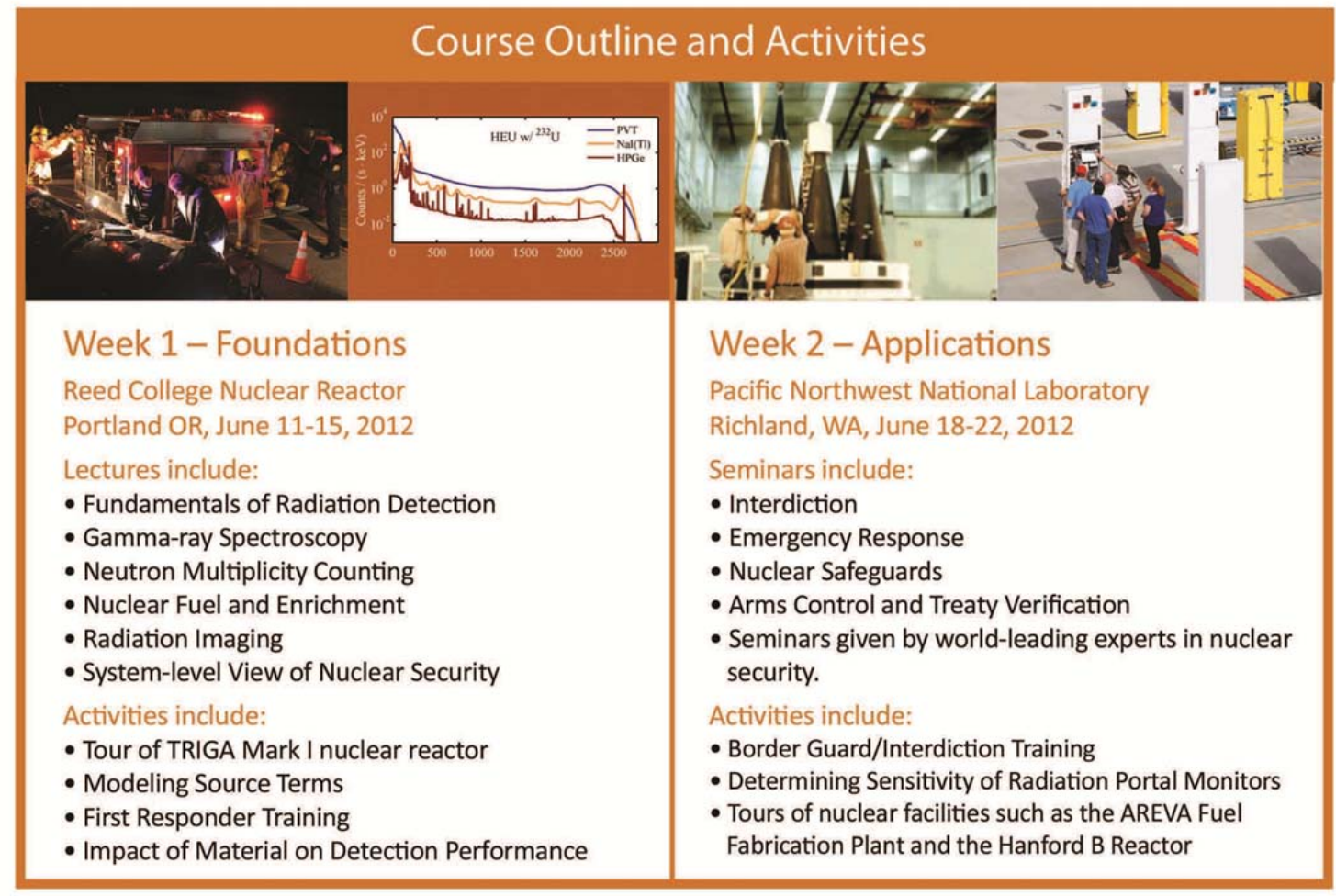

\section{Eligibility}

The course is designed for graduate students in science and engineering programs with an interest in careers within the US national laboratory system or federal

government agencies responsible for nuclear security. Experienced upper-level undergraduates will also be considered. Special consideration will be given to students whose research is funded by NNSA's Office of Nonproliferation and Verification R\&D (NA-22), and students performing research in fields with potential nuclear security applications.

Only US citizens are eligible for this course.

\section{Instructors}

Robert C. Runkle is a nuclear physicist, James E. Baciak is a nuclear engineer and Jean A. Stave is a scientist and former educator.

\section{For More Information}

For more information, or to request an application, please contact:

Dr. James Baciak

Pacific Northwest National Laboratory

Phone: (509) 375-3088

James.Baciak@pnnl.gov

Application Deadline: March 1, 2012

\section{About PNNL}

Pacific Northwest National Laboratory is a Department of Energy Office of Science national laboratory where interdisciplinary teams advance science and technology and deliver solutions to America's most intractable problems in energy, the environment and national security. PNNL employs 4,900 staff, has an annual budget of nearly $\$ 1.1$ billion, and has been managed by Ohio-based Battelle since the lab's inception in 1965.

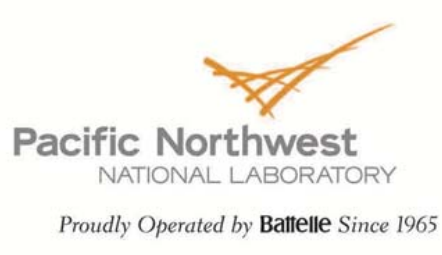


Appendix B

Student Application 


\title{
Radiation Detection for Nuclear Security Summer School
}

\author{
11-22 June 2012 \\ Application instructions
}

Please read these instructions completely.

\section{Objective}

Students in the Radiation Detection for Nuclear Security Summer School will participate in a 2-week summer school that combines lectures, real-world technology demonstrations, and tours of operational facilities with relevance to nuclear security. The summer school will emphasize mission needs for radiation detection in nuclear security with heavy emphasis on demonstrations and discussion on current fielded technologies and the real-world challenges that are not normally considered in an academic setting. The summer school will prepare students interested in working for national laboratories or the United States government with an understanding of the current challenges for applied technology.

\section{Eligibility}

The targeted student population consists of those most considering future employment at national laboratories.

Students must be U.S. citizens.

Students must be enrolled in graduate degree program in a field relevant to radiation detection including nuclear engineering, nuclear physics, nuclear chemistry, high-energy physics, ...

Priority will be given to those students closest to graduation.

It is strongly recommended that students bring a laptop to the summer school.

\section{Application Procedure}

- Complete this application

- Send a resume or CV

- Send a copy of university transcripts. Unofficial transcripts are acceptable.

- Provide contact information for your research advisor or other individual who can speak to your research experience.

Application Deadline: 1 March 2012

Admission Notification: on or before 1 April 2012 


\section{Pre- Arrival Procedures}

All students accepted into the summer school must complete and submit the following before arrival:

- PNNL on-line orientation and training.

- PNNL application for temporary dosimetry.

Information and forms concerning orientation, training, and temporary dosimetry will be provided upon acceptance into the summer school.

\section{Costs and Fees}

There is no charge for the Radiation Detection for Nuclear Security Summer School. However, students are responsible for funding their own meals, lodging and transportation to and from Portland, Washington, and between Portland, Oregon and Richland, Washington. Additional travel information (accommodations for the summer school with discounted rates, directions for arrival and departure, weekday meals, etc.) will be provided with the admission notification. 
Radiation Detection for Nuclear Security Summer School Application

Personal Information

Name:

(last) (first) (middle initial)

Graduate school years completed: Expected graduate date:

Home College/University:

Email address:

Faculty Advisor and email address:

Undergraduate College/University:

Major:

GPA:

Permanent Address

(street)

(city)

(state)

(zip code)

Telephone number:

Local School Address (leave blank if same as permanent address)

(street)

(city)

(state)

(zip code)

Telephone number:

Dates current address is valid: 


\section{Additional Information}

1. In 300 words or less, briefly describe any research in which you are currently participating.

E-mail completed application to:

James Baciak

Pacific Northwest National Laboratory

902 Battelle Boulevard

P.O. Box 999, MSIN J4-65

Richland, WA 99352

Tel: 509-375-3008

james.baciak@pnnl.gov 
Appendix C

Schedule of Events 


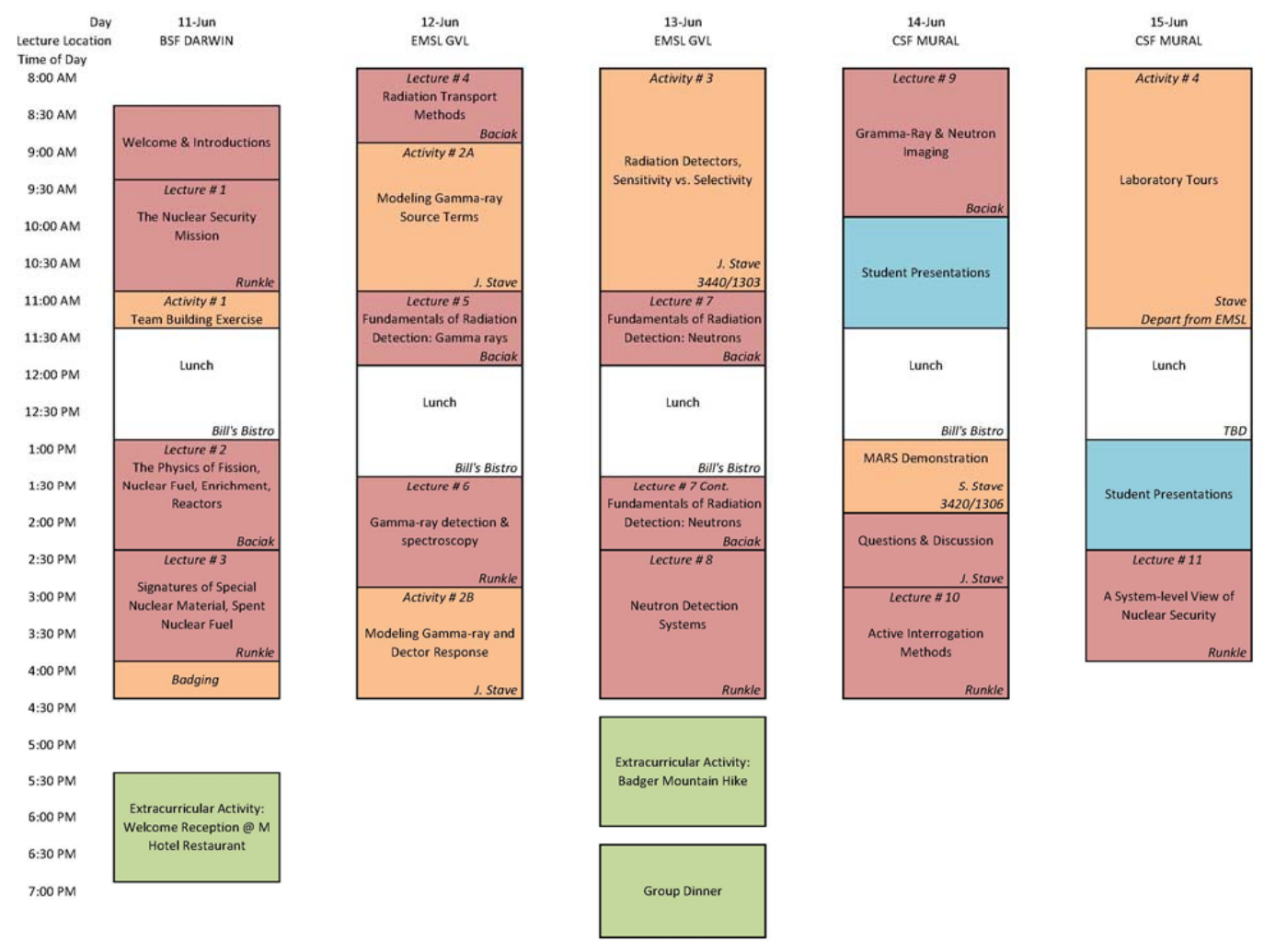




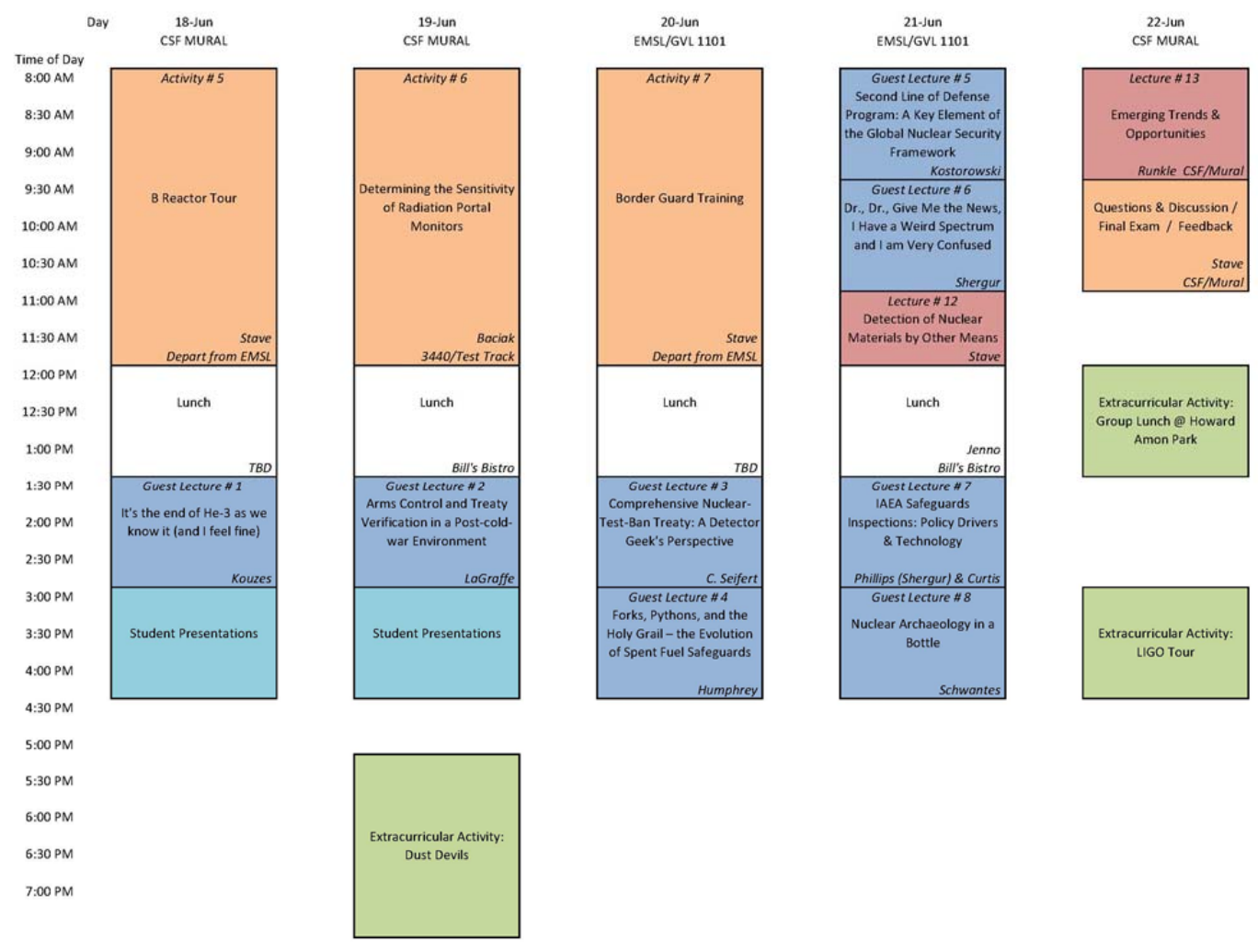


Appendix D

Photo Gallery 


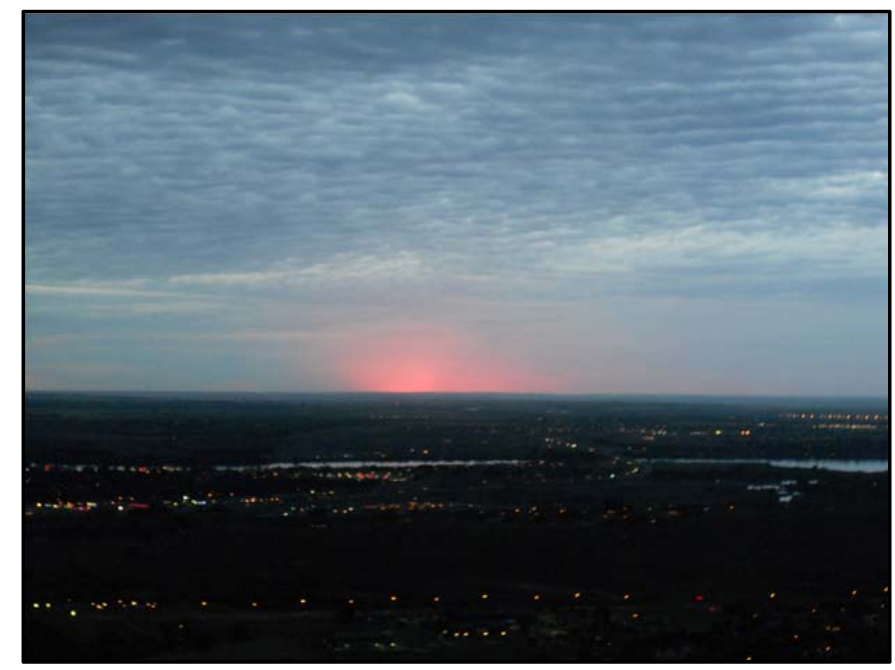

Figure D.1. View of sunrise above Richland, WA. Robert Runkle led a group of the course participants to the top of Badger Mountain on the morning of the final day of the course.
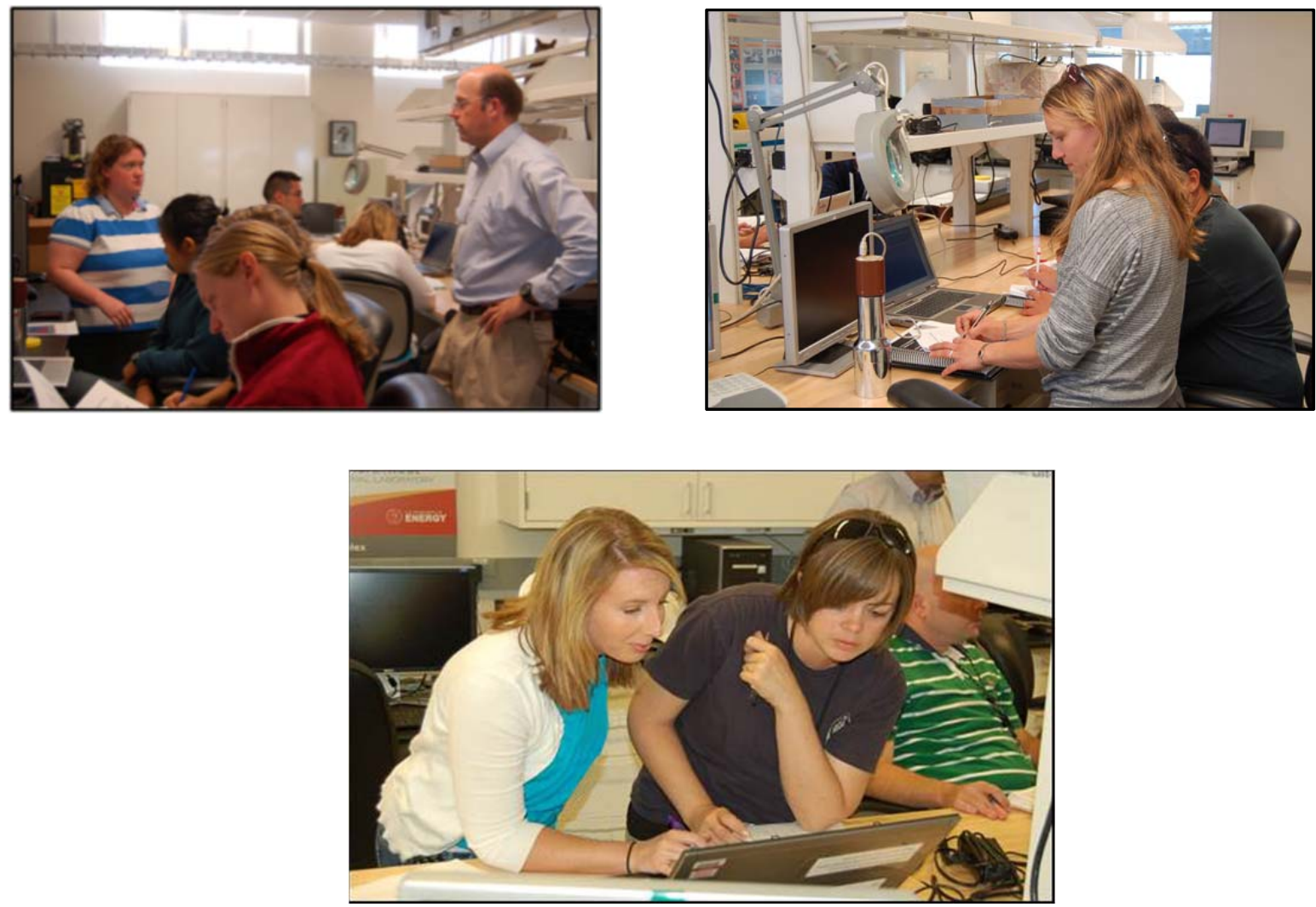

Figure D.2. Students study aspects, such as sensitivity and resolution, of different types of detectors in the radiation detectors: sensitivity vs. selectivity activity. 


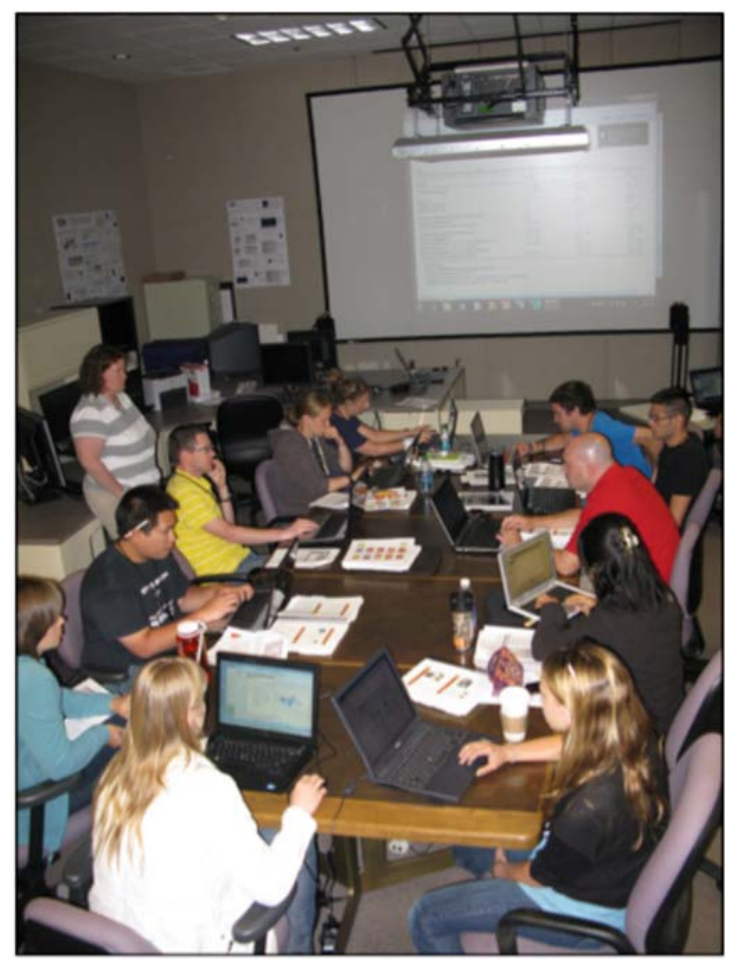

Figure D.3. Students use the radiation modeling software SYNTH to study source terms and detector response.

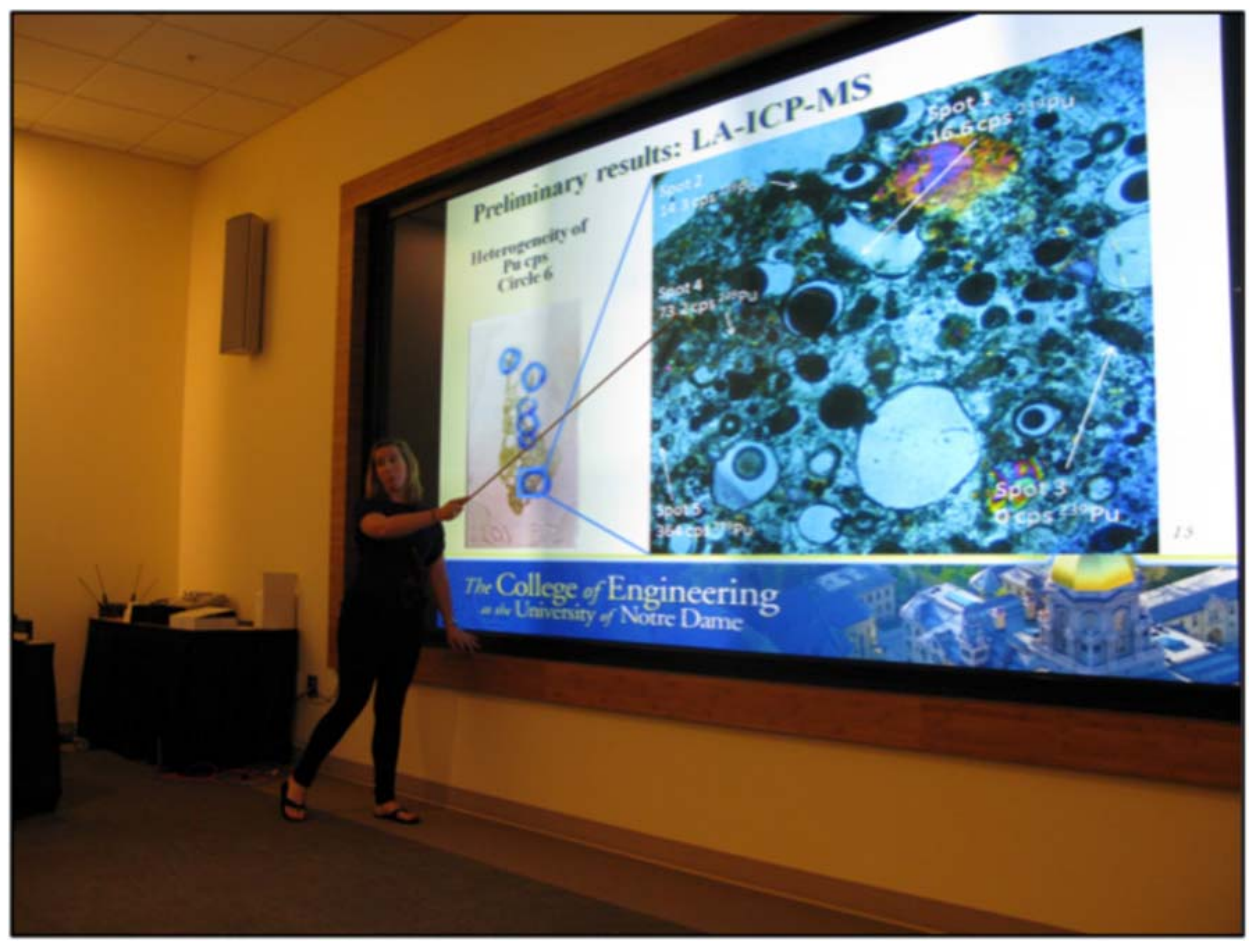

Figure D.4. Summer school participant, Elizabeth Koeman, presents her research to fellow participants. 


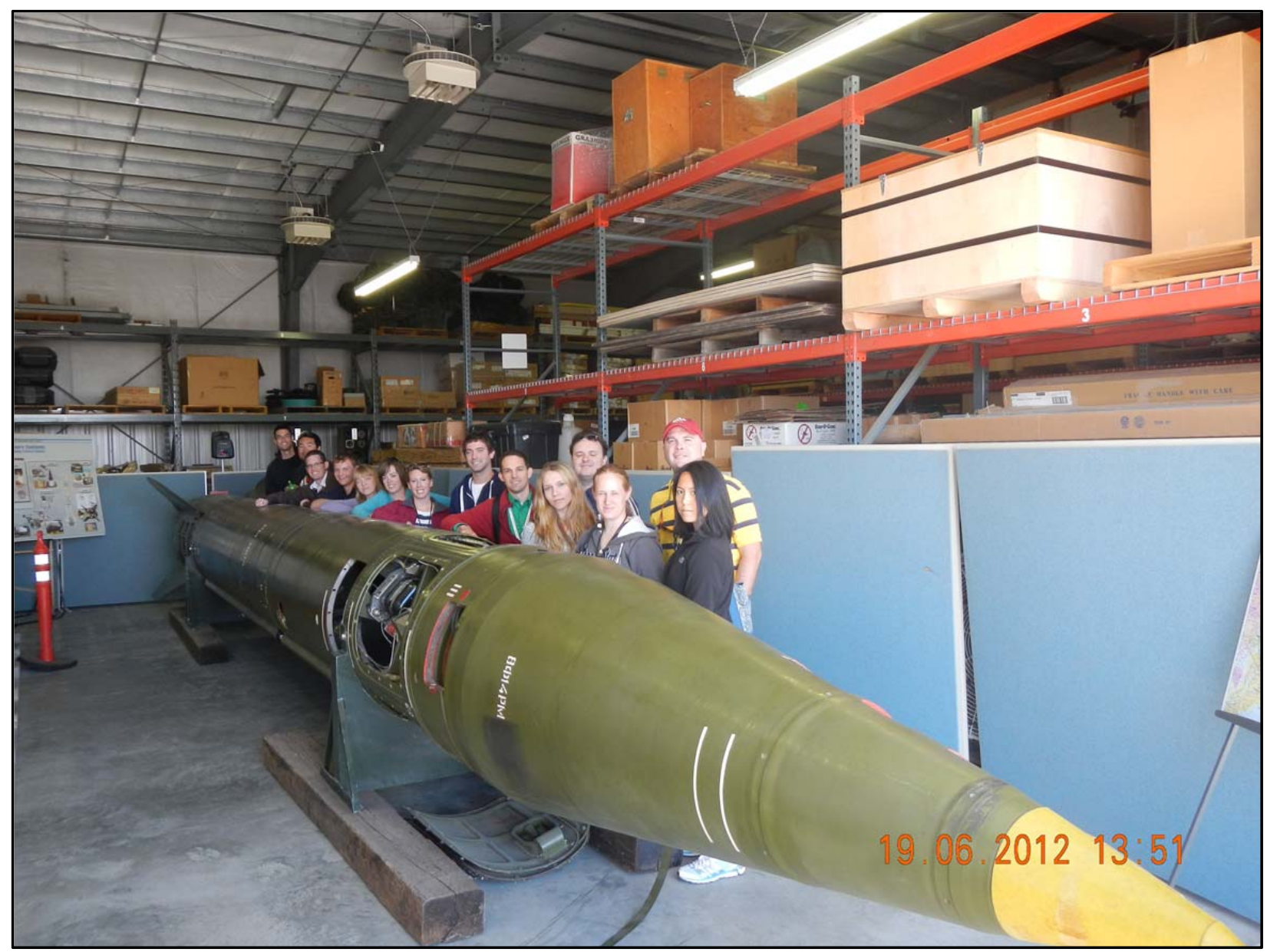

Figure D.5. Students at the HAMMER training facility stand next to a mock nuclear warhead used in demonstrations of treaty verification. 
Appendix E

Extracurricular Activities 
Table E.1. Extracurricular Activities

\section{DATE/ACTIVITY}

Monday, 11 June

Following the first day of the summer school, students, lecturers, and guest lecturers Welcome Reception were invited for light food, beverages, and pool at the M Hotel.

Friday, 15 June \& Students braved the desert heat and enjoyed a local favorite hiking route.

Friday, 22 June

Badger Mountain Hike

Sunday, 18 June

Jim Baciak served as a tour guide to students at local wineries in the Tri Cities.

Wine Tasting

Tuesday, 19 June Dust Devils Baseball

Students attended a game of the local professional baseball league.

Thursday, 21 June

Jean Stave hosted students at her home. They cooked dinner funded by the lecturers. 


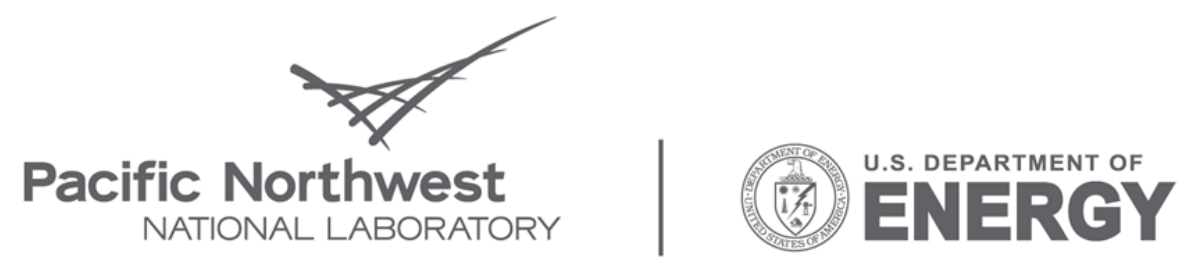

Proudly Operated by Battelle Since 1965

902 Battelle Boulevard

P.O. Box 999

Richland, WA 99352

1-888-375-PNNL (7665)

www.pnl.gov 